\title{
CHILDREN'S ECOLOGICAL KNOWLEDGE: DRAWINGS AS A TOOL FOR ETHNOECOLOGISTS (GABON, MADAGASCAR)
}

\author{
Stéphanie M. CARriere, Catherine SABINOT, Hélène PAGEZY*
}

Résumé - Le savoir écologique des enfants : les dessins comme outils pour les ethnoécologues (Gabon, Madagascar). Les enfants ont longtemps été marginalisés dans les recherches en ethnoécologie portant sur le savoir écologique traditionnel (TEK) et les représentations de la nature. Il existe peu d'outils et de ressources pour analyser le monde des enfants en ethnoécologie. Cependant, de nombreuses questions et de nombreux thèmes, particulièrement au sujet de la production et de la transmission du TEK, concernent les enfants. Ces derniers construisent leurs propres traditions et compétences, lesquelles façonnent leurs propres productions culturelles, ainsi que celles des adultes. Le TEK des enfants devrait donc être analysé au même titre que celui des adultes dans la recherche en ethnoécologie. Les enfants sont à la fois producteurs et dépositaires du savoir écologique et des valeurs sociétales. Ils mobilisent ces dernières de manière autonome pour interagir avec leur environnement afin d'améliorer leurs conditions de vie, de mener leurs propres expériences, et de s'adapter à un monde qui change. Cet article, principalement fondé sur un terrain effectué au Gabon et à Madagascar, vise à revisiter le TEK des enfants, à analyser et à discuter l'intérêt pratique et heuristique d'un nouvel outil en ethnoécologie: les dessins d'enfants.

Mots clés - Représentations sociales ; méthode ; Gabon ; Madagascar

Abstract - Children have long been marginalized in ethnoecological research on traditional ecological knowledge (TEK) and representations of nature. Few tools or resources exist to address the children's world in ethnoecology. Nonetheless, many questions and themes, especially around the production and transmission of TEK, concern children. Children build their own traditions and skills, which shape both their own cultural productions and those of adults. Children's TEK consequently should be considered alongside that of adults in ethnoecological research. Children are both producers and repositories of ecological knowledge and societal values. They mobilize these in an autonomous manner to interact with their environment in order to improve their living conditions, conduct experiments, and adjust to a changing world. Based mainly on fieldwork conducted in Gabon and Madagascar, this paper aims to reconsider children's TEK, analyse and discuss the practical and heuristic interest of a new tool in ethnoecology: children's drawings.

Keywords - Social representations; method; Gabon; Madagascar

Resumen - El conocimiento ecológico de los niños: los dibujos como herramientas para los etnoecólogos (Gabón, Madagascar). Los niños siempre han sido marginados en las investigaciones etnoecológicas del conocimiento ecológico tradicional (TEK) y de las representaciones de la naturaleza. Sin embargo, existen pocas herramientas y pocos recursos existen para indagar el mundo de los niños en etnoecología. Por lo tanto, numerosas

\footnotetext{
* Stéphanie M. Carrière, UMR 220 GRED, IRD, Montpellier, France, stephanie.carriere@ird.fr ; Catherine Sabinot, UMR 228 ESPACE-DEV, IRD, Nouméa, Nouvelle-Calédonie, France, catherine.sabinot@ird.fr ; Hélène Pagezył, UMR 7206 Eco-Anthropologie \& Ethnobiologie, CNRS-MNHN, Paris, France
} 
cuestiones y numerosos temas, en particular acerca de la producción y de la transmisión de los TEK, se refieren a los niños. Los niños construyen sus propias tradiciones y sus propias habilidades que dan cuerpo no solo a sus propias producciones culturales sino a las de los adultos. El TEK de los niños se debería analizar como aquel de los adultos en la investigación ethnoecológica. Los niños son productores y depositarios del saber ecológico y de las valores societales. Éstas están movilizados de manera autónoma, para interactuar con su medio ambiente, con el fin de mejorar sus condiciones de vida, de experimentar y de adaptarse a un mundo cambiante. Este artículo, que se basa principalmente en un trabajo de campo en Gabón y Madagascar, tiene como objetivo de re-considerar el TEK de los niños y de analizar y discutir la relevancia práctica y heurística de esa nueva herramienta en etnoecología: los dibujos de los niños.

Palabras claves - Representaciones sociales; método; Gabón; Madagascar

\section{INTRODUCTION}

WHEN ETHNOECOLOGISTS STUDY the interactions of a given society with the natural world, they attempt to examine how people think about their natural environment and use its components (Toledo 1992; Hunn 2007). They collect the names of plants and animals, describe knowledge and skills, and analyze the origins, evolution and transmission of knowledge about plants and forests, coral reefs and marine animals (Ellen 1993). Ethnoecologists might understand how people conceptualize and use nature based on how people have experienced it and on what people learn from their elders and others (Ellen 2006). However, all of the members of a given society actually do not hold exactly the same representations, knowledge and values regarding their environment (Ghimire et al. 2004). Although each individual and social group (identified by gender, practices, experience, age) have their own way of being in the world, they do not all receive the same degree of attention in the fields of ethnoecology and environmental anthropology ${ }^{1}$. Indeed, while participant observation covers all generations, the collection of data through structured and semi-structured interviews is usually done only with adults. Anthropologists and ethnoecologists have tended to consider children only as part of specific themes, such as child-mother interactions and learning and teaching processes, but rarely as a research target group on their own (Friedl 2002). Children consequently are not generally or systematically interviewed. Children's ecological knowledge ${ }^{2}$ and representations of nature are in particular widely ignored in ethnoecological studies. Nevertheless, children build their own representations, knowledge, know-how,

\footnotetext{
${ }^{1}$ Both ethnoecology and environmental anthropology terms may be employed for talking about sciences that study relationships between societies and their environment. Ethnoecology is more relevant for this paper. Nevertheless, we argue that ethnoecology as well as environmental anthropology should integrate ecological, social and political considerations to achieve a comprehensive understanding of human and non-human interrelations.

${ }^{2}$ TEK (Traditional Environmental Knowledge) as well as concepts such as IK (Indigenous Knowledge) and LEK (Local Environmental Knowledge) also have been used and might have been relevant. In this paper, the concept of "ecological knowledge" is used to emphasize the "ecological" character of knowledge and to avoid misunderstanding regarding the notion of tradition, which often is considered without acknowledging its dynamic character.
} 
traditions, and skills, which shape both their own cultural productions and those of adults (Gallois et al. 2017; Hirschfeld 2002). Their knowledge, sometimes called "children's culture" (Hirschfeld 2002), must be seen as being both conditioned by and complementary to that of adults in an ethnoecology analysis striving to reveal the interactions between a society and its environment.

As many questions and themes in ethnoecological research, especially those involving the content, production and transmission of traditional ecological knowledge, concern the child's sphere, an interdisciplinary team developed an innovative approach based on children's drawings. The main objectives were to document children's ecological knowledge, increase its visibility, and deepen understanding of the relationship between non-humans and humans during all stages of life, including childhood. A one-year exhibition at the Musée de l'Homme in Paris (2008) and an interdisciplinary book intended for the general public were the main outputs of this work (Pagezy et al. 2010).

Using our experience of the children drawing process in Gabon and Madagascar, this paper has three objectives. The first is to reconsider children's ecological knowledge and to lay down some conceptual milestones for taking children's ecological knowledge into account in ethnoecology. The second is to formalize the use of this new children's drawings tool by discussing the methodological issues that have emerged during the 'children drawing process'. The last is to demonstrate the heuristic interest of the tool in ethnoecology and determine the best conditions for its use.

\section{ETHNOECOLOGY OF CHILDREN VERSUS ETHNOECOLOGY WITH CHILDREN}

\section{What is "adult" ethnoecology?}

Ethnoecology developed out of ethnobiology (Berlin et al. 1973) during the 1970s and $1980 \mathrm{~s}^{3}$. It investigates how local knowledge about the non-human sphere (flora, fauna, abiotic elements) is translated in daily life through customs and practices. Ethnoecology involves understanding the manner through which ecological knowledge influences the way of being in the world of human groups. This knowledge is related to particular perceptions of the environment, practices, present worldviews, and dynamic and diverse ways of thinking about and organizing the world (Hviding 1996; Ingold 2004; Sabinot \& Lescureux forthcoming; Toledo 1992). Their description and analysis allow ethnoecologists to reveal each specific sociocultural context in which knowledge is built and expressed, especially regarding the interactions between societies and their environments.

Adults have long been the only individuals interviewed by ethnoecologists when they seek to describe how information is categorized, classified, and organized into knowledge systems. For example, prior to the fieldwork and data collection related

\footnotetext{
${ }^{3}$ For a history of ethnoecology, see Hunn (2007).
} 
to the Nature du monde: dessins d'enfants (Nature of the world: children's drawings) exhibition and book project (Pagezy et al. 2010), none of the authors had focused exclusively on children's knowledge, excepted Battesti (2007) and Dounias (2007). Ethnoecologists seeking to describe and assess individual ecological knowledge within a population usually pay attention to the sample size and stratify their sample according to fairly standard criteria such as age, gender, place of residence, origin, level of education, occupation, etc., but they rarely consider other issues related to specific social groups such as children. Nonetheless, ethnoecological studies focused specifically on children can help a better understanding of how, when and under what conditions ethnoecological knowledge emerges, builds, accumulates, consolidates and is transmitted (Reyes-García et al. 2007; Setalaphruk \& Price 2007). Given the differences in language and ways of thinking between children and adults, the different amounts of time usually dedicated to each generation by researchers, the authors of this paper set out to develop an innovative tool for understanding children's ecological knowledge and their way of being in the world. This drawing tool may be considered as a complement to the classical methods used with adults, and more rarely with children, in ethnoecology.

\section{Why and how to add "child" ethnoecology?}

As children are active, competent and capable of autonomous actions (Samuelsson et al. 2015), they are both producers and repositories of ecological knowledge, practices and social values (Setalaphruk \& Price 2007). They mobilize these to interact with their environment and improve their living conditions (dwelling with nonhumans, subsistence strategies, land access, interaction with adults, gender issues...), and test and adjust them in a changing world. In describing how ethnoecology with children allows us to understand interactions between humans and non-humans, we will first focus on the topics and questions that can be addressed through the "children drawing process"4.

Since the 1960s, the analysis of children's drawings has been a commonly used tool in psychosociology. By considering children's effective rather than objective reality, drawings have allowed psychologists to understand how children represent their reality and environment. Before the use of drawings became common in the realm of psychology, G.H. Luquet (1927), a philosopher and ethnologist, was the first to devote a book to children's drawings. Since the 1970s, geographers also have used drawings (with children and adults) and mental maps (usually with adults) to understand children's relationships with space and territory (Fournand 2003). Finally, some ethnoecologists such as Battesti (2007) and Dounias (2007) have used diverse graphic representations, including children's drawings, in some of their research because they deem that "a drawing is a message that speaks, narrates, explains, much of what children do not yet know how to express verbally" (Dounias

\footnotetext{
${ }^{4}$ Photographic images produced by children are another means to apprehend places and activities that matter most to children (Gearhart 2013), and could complement a drawing-based approach.
} 


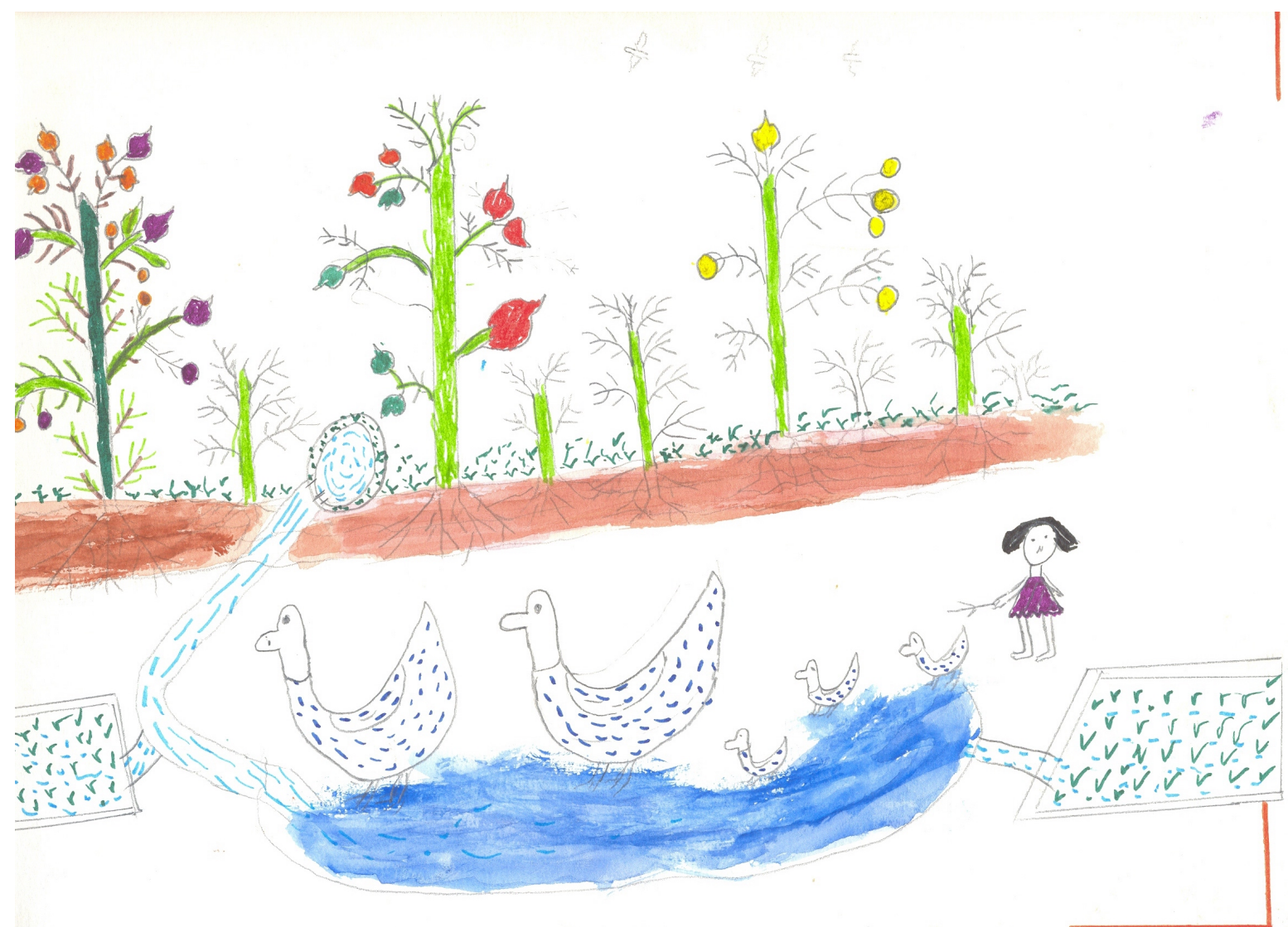

Around a pond rano dobo, where fish-farming is regularly practiced, the child drew geese. This pond is located downstream of a source loha rano, represented by a circle. Two rice paddy fields tanimbary are fed from this pond.

Like these researchers, we hold that children's drawings, as well as other systematic and "rapid" methods, could help to better understand children's ecological knowledge when complementary semi-structured interviews are conducted and when researchers already have a good understanding of the related society. The children drawing method can be compared to the "free listing" technique used with adults (Atran et al. 2002) and children (Gallois et al. 2017; Setalaphruk \& Price 2007). The limiting parameter of this technique is not a fixed period of time in which items may be listed, but rather the space available on the sheet (when the sheet is filled, the list is stopped). The layout rank of drawn items may also be used to evaluate the relative importance of each item. The second part of the method (interviews), in which the children speak about the morphology or colors of an item in their drawings, can be compared with the specimens identification method used with adults (Begossi 1996) and children (Gallois et al. 2017; Setalaphruk \& Price 2007). If a species is drawn with a given number of characteristics, it is because it is identified, named, and therefore known; this is practical knowledge obtained by a kind of self-declaration (Ticktin \& Johns 2002). The children drawing method may also lead to the emergence of another type of information linked with theoretical ecological knowledge and social representation. Indeed, elements about 
adult activities (agriculture, hunting, fishing, gathering, rituals, etc.) may appear in a child's drawings, although the child is personally not always able to practice these activities. These are technical or social acquisitions (sexual division of tasks) linked to informal observations (no real practical learning) while children participate in family activities (Setalaphruk \& Price 2007).

Figure 2: C. 13-year-old girl, Mayumba, Gabon

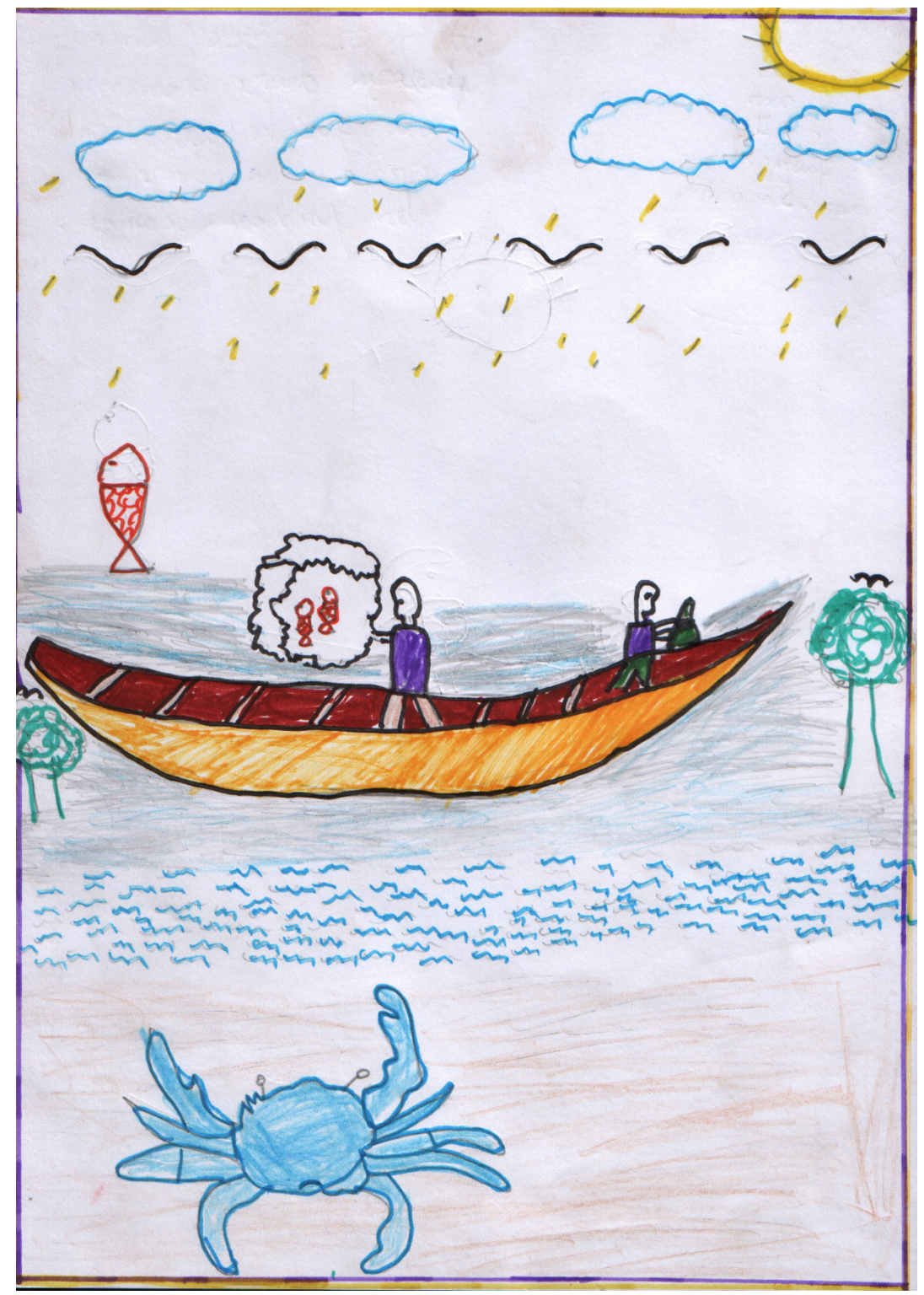

A father and his child are fishing with casting nets. Learning through doing is the most important way to acquire knowledge and know-how on a boat.

Figure 1 shows hydraulic knowledge about how to divert and use water for rice fields, from an upstream source, via a water storage basin and finally through secondary irrigation canals to supply a rice field ( $c f$. Figure 1 above). Many children in Gabon also drew themselves with an adult (father, mother, uncle...) doing an activity ( $c f$. Figure 2 above). They explain that they do - practice - with adults. They thus learn in an active way by "doing" or "making". For other activities, transmitted from parents to children, children observe and learn in a passive way; they are 
present during the action, even helping the parents, but without actually putting their skills into practice (Hewlett \& Cavalli-Sforza 1986; Zarger \& Stepp 2004). Participant observation by ethnoecologists in the field reveals that children have not yet totally acquired their parents' technical skills, yet they can possess dormant theoretical knowledge, which patiently waits to materialize.

\section{How to collect data from children drawings: some methodological insights}

The following methodology is the same as the one succinctly described by Pagezy et al. (2010). As children under the age of eight do not usually succeed in representing items or actions in fine detail, while children over the age of 13 can lose their spontaneity in front of a teacher or observer, only children aged nine to 13 take part in the drawings process. At this age, most of children have already learned traditional ecological knowledge and skills and the semi-structured interview with the researcher allows this knowledge to be collected with minimal differences in the level between the different children's ecological knowledge (Ohmagari \& Berkes 1997; Ruddle 1993). After each drawing is collected, an interview is conducted to understand precisely what has been represented (the name of plants and animals, the type of ecosystems, the interactions between items, the landscape and the activities), and also sometimes why each item was represented.

A school usually is the most suitable and practical place to set up drawing workshops, both for logistical reasons and to obtain a representative sample of educated children. Teachers are asked to refrain from giving the children any instructions or advice regarding how the drawings should be made. The children are told that the purpose of the workshop is simply to make drawings, not to demonstrate what they have learned in class. The drawings are not evaluated or noted. Once the children are settled in the classroom, a very simple instruction is given and translated into the children's local (maternal) language: draw nature, your nature, your environment. The children are then given the opportunity to ask any questions they may have about the instructions in a one-to-one interaction, i.e., one child/one researcher. This is to avoid imposing a "bias" on all of the children in terms of how to conceive of "nature" or the "environment" . Explanations were periodically given on the techniques proposed - how to use black pencils and gum, color pencils, felt pens and paint (some children, as in Madagascar, may not have used these tools before). Children draw from one to two hours depending on their speed; no time limit is ever imposed. When the child finishes his/er drawing, s/he presents it to the researcher who then conducts an informal interview with him/er. During this exchange, the researcher aims to understand the drawing, asking for the names of the items depicted and explanations regarding activities and landscapes

\footnotetext{
${ }^{5}$ Depending on the topic studied, the researcher undertakes preliminary work to find the most appropriate terms for a given society, for example the notion of nature is not always formulated as such everywhere and will not always be the term used with the children.
} 
drawn with particular care to better understand how the child shares his/er daily experience. The child also can express his/her feelings about the drawing session. The child's name, date, age, gender, class and place of residence are noted on the back of the sheet. During the workshop, the researchers note the location of each child in the classroom in order to be able to spot any eventual copying phenomena. Teachers and other attendants ensure that the workshops run smoothly (replacing sheets if necessary, answering questions...). Particular attention is given to the vernacular terms used for naming elements in the drawings. In Gabon, for example, some were systematically named in French while others were only named in vernacular terms. The capacity of several children to precisely draw sea resources and to name a few fish in different languages - French, Vili (Gabonese language), Phla (Beninese language) - shows the extent of the interactions between various communities regarding fish (fishing, trade, tales, etc.).

\section{The children who draw and their way of life in Madagascar and Gabon}

Between 2004 and 2006, more than 300 children in Gabon and Madagascar drew for the authors. The research aimed to understand the children's ecological knowledge and their way of perceiving and describing their environment (marine, coastal, forest or rural).

In Madagascar, the two villages chosen, Merina and Betsileo, are located on the highlands in two ecologically, socio-economically and ethnically different areas (Carrière 2010a; Carrière \& Gastineau 2010a). The majority of the children attend school and lead a rural life in close connection with agricultural and livestock activities. Merina village is located near the small city of Ampitatafika along a highway connecting the capital, Antananarivo, and the city of Antsirabe. It is one of the many stops of the bush taxis used by people to travel in the country. In contrast, Betsileo village, situated at the southwest corner of Ranomafana National Park, is more landlocked and people must often travel by foot. Many Betsileo children have never been to the city or even left their village. In both villages, a river and/or well are the source of water for families and also a place for children to bath and play; many children fish during their free time. Agricultural activities in the two villages are quite similar and are based on permanent rice cultivation, subsistence agriculture and zebu breeding. However, small-scale breeding activities are more developed and diversified (ducks, geese, fish, pigs and zebu) in Merina, and there are fruit tree plantations (fruit orchards for income generation, cf. Figure 3 below). 
Figure 3: R.F., 14-year-old boy, Merina region, Madagascar

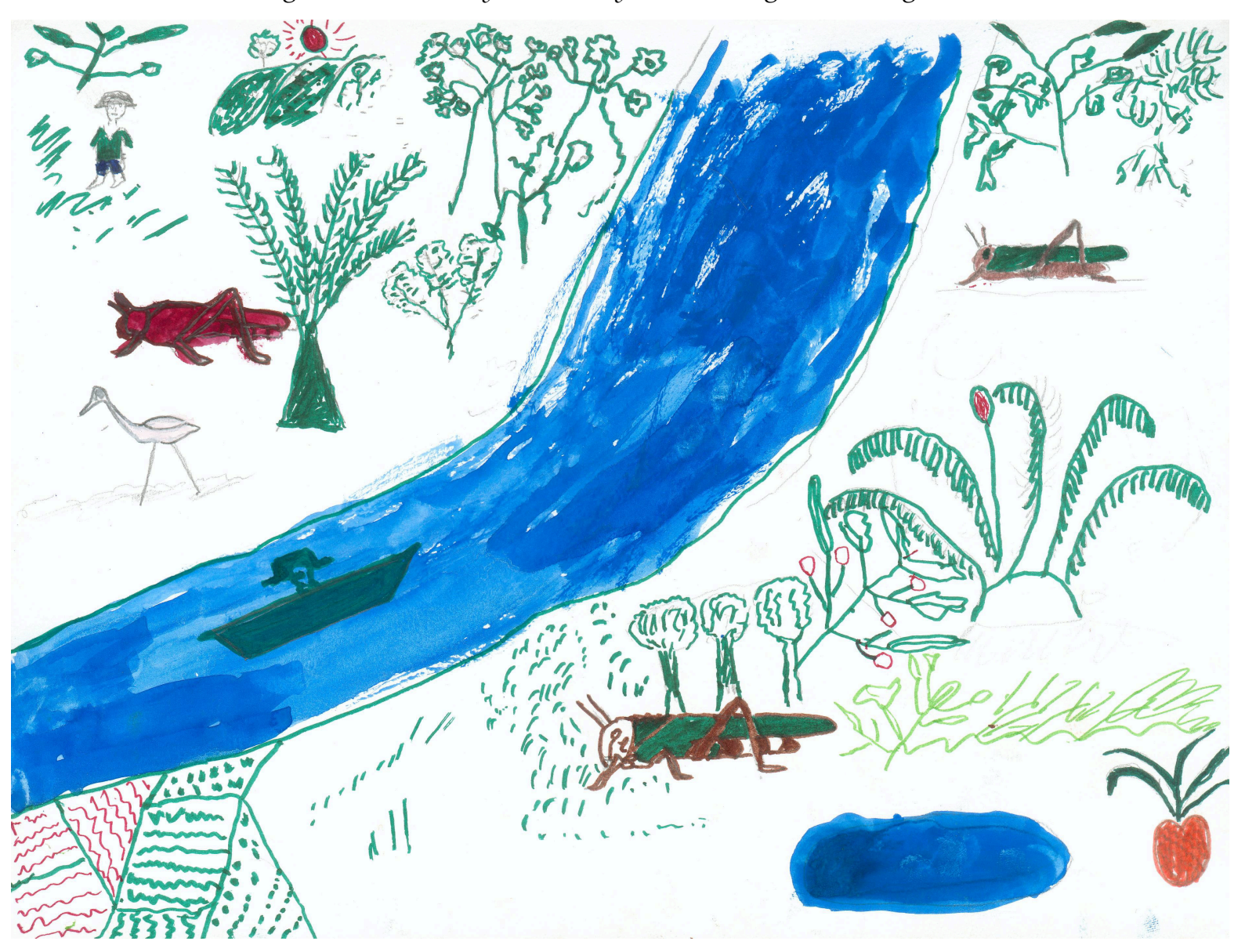

Domesticated nature illustrated by a landscape where human activities and domestic plants and animals dominate. The river is drawn with a boat and a fisherman. The animals represented are the grasshopper, a crop enemy, and a bird, frequently observed in the fields. Below left, a pond in which fish farming activities are carried out. Plots of rice are drawn on the bottom left adjoining the bank of the river. There is also a pineapple on the lower right, dahlia, banana trees on the right, khaki at the top right and cotton at the top. The hills on the top left under the sun are green because they are dominated by reforestation trees such as pines and eucalyptus. To finish, this child represented himself in the drawing (Carrière \& Gastineau 2010c, 2010d).

In contrast, forest-related activities (hunting, fishing, picking, and selective wood cutting) predominate in Betsileo. These differences are due to the total absence of natural forests in Merina village, where children are in daily contact with exotic tree plantations (pine, acacia or eucalyptus ${ }^{6}$ ), while a mid-altitude tropical forest lies near Betsileo village. In both villages, children spend a lot of time after school in the fields accompanying parents as they work or in the pastures to guard the zebu. The children of these two villages are close to the natural world, they know the animal and plant species, which they use and see. What differs between them is the nature of the latter: in Merina village, both the species and the landscapes represented in

\footnotetext{
${ }^{6}$ The majority of the Malagasy highlands have been periodically reforested with pines (for wood and erosion control), acacias (notably for tannins), and eucalyptus (wood and charcoal) thanks to the villagers' plantations. These three useful exotic species are present in both study areas. Most of these plantations are located on old savannas (Kull et al. 2013).
} 
Figure 3 are domesticated, while in Betsileo village, nature is represented as a mixture of domestic and wild species ( $c f$. Figure 4 below).

Figure 4: R.J.C., 14-year-old boy, Betsileo region, Madagascar

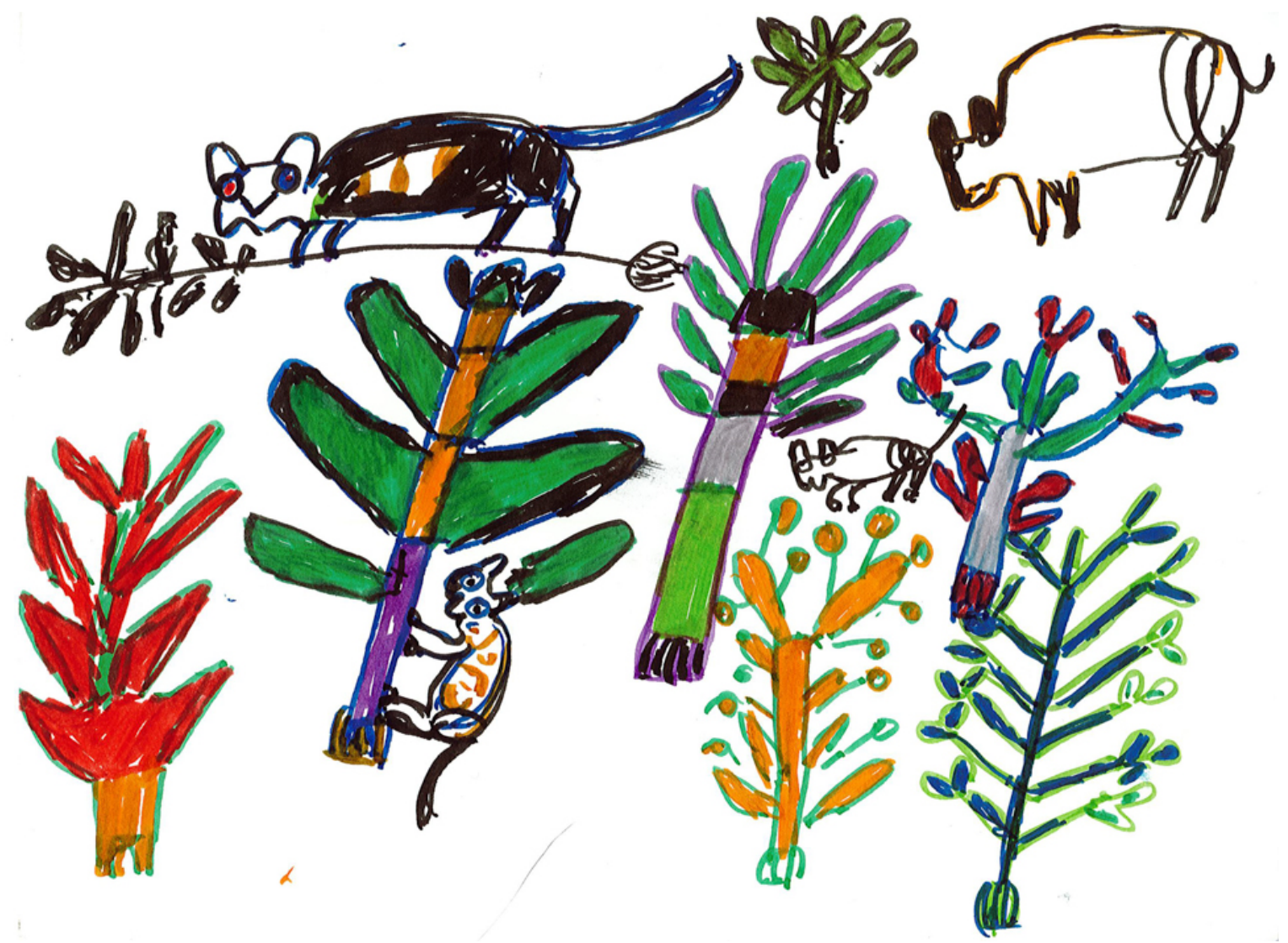

The drawing illustrates the "wilderness" on the forest edge. Many of the trees drawn represent useful species in the natural forest. The four animals drawn are all present in the forest, even if sometimes they leave it, such as wild boar and lemurs (Carrière 2010c).

In both villages, children are involved in subsistence and domestic activities and rituals (Carrière 2010b; Carrière \& Gastineau 2010b). Through their participatory observation, they gather ecological knowledge and know-how useful for their future adult life.

Along the Gabonese coast, native populations and migrant fisher communities live side-by-side, continuously building changing life spaces together. In this country, and especially in the villages where the drawings were made, West Africans (from Benin, Ghana and Nigeria) usually fish in the ocean while the Gabonese and a few Senegalese fish in lagoons and rivers. The Gabonese are also engaged in horticultural activities. In this multicultural context, there are many trade and linguistic exchanges, mixed marriages, and exchanges of knowledge, know-how and know-being (Sabinot 2007). Local and migrant communities are being built reciprocally in a space resulting from interrelationships between groups, and between groups and their coastal environment. Children from seven villages on the Gabonese coast, in particular from two schools in Nyanga region, participated in the drawing workshops. Their drawings were always prompted by the same question: 
draw your nature, your surroundings; they drew at school or exceptionally at home. In 2015 and 2016, two hundred and twenty drawings were collected and extensive ethnographical fieldwork was conducted (Sabinot 2008). The drawings show moments from everyday life, fishing scenes, landscapes, objects and tools, animal and vegetable species. In Nyanga region, the drawings reveal the importance of boats in the daily life of the society, including children. Of the 201 children in the region who made a drawing, $86(41 \%)$ sketched a boat. About 78 children drew a dugout canoe (some with, some without, a motor), eight drew a boat equipped with a cockpit and steering wheel. There are zodiacs of tourism companies, fisheries department, national park managers, fishing and travel vessels. The drawings also show the identity dimension of the boats: overall shape, size, edging, position in relation to the sea, and colors are elements to identify the owner of the boat. Indeed, the children usually drew a boat owned by one of their relatives, one they use daily (cf. Figure 5 below).

Figure 5a: A.M.H., 12-year-old boy, L'office quarter, Gabon

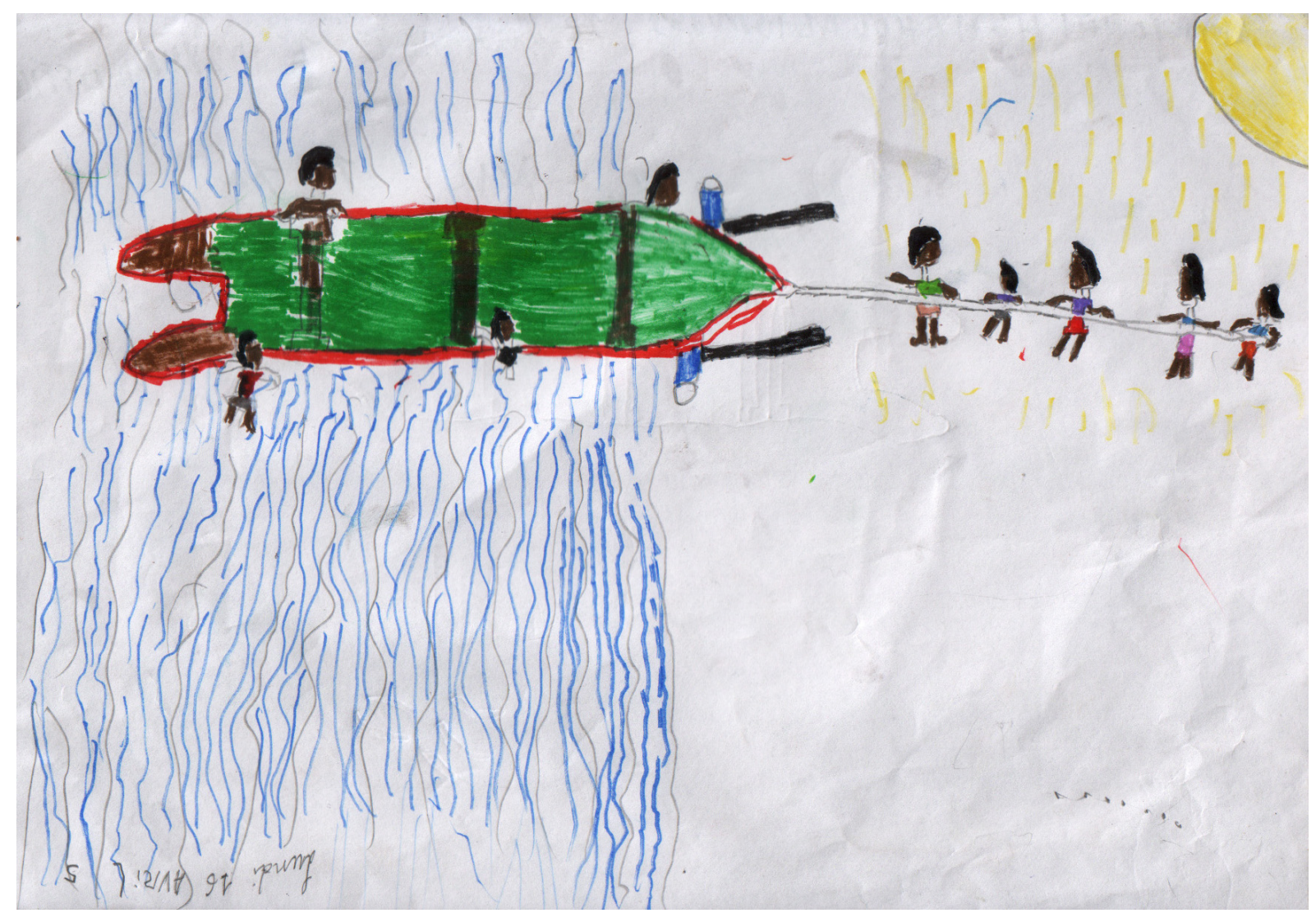

a) The boat - "Beninese model" - is a big dugout canoe, edged by boards/planks, used for the high seas. After each fishing trip, men of the quarter gather to help their colleagues to pull the canoe up to the top of the beach to protect it from high tide. 
Figure 5b: D.S., 14-year-old girl, Ndindi region, Gabon

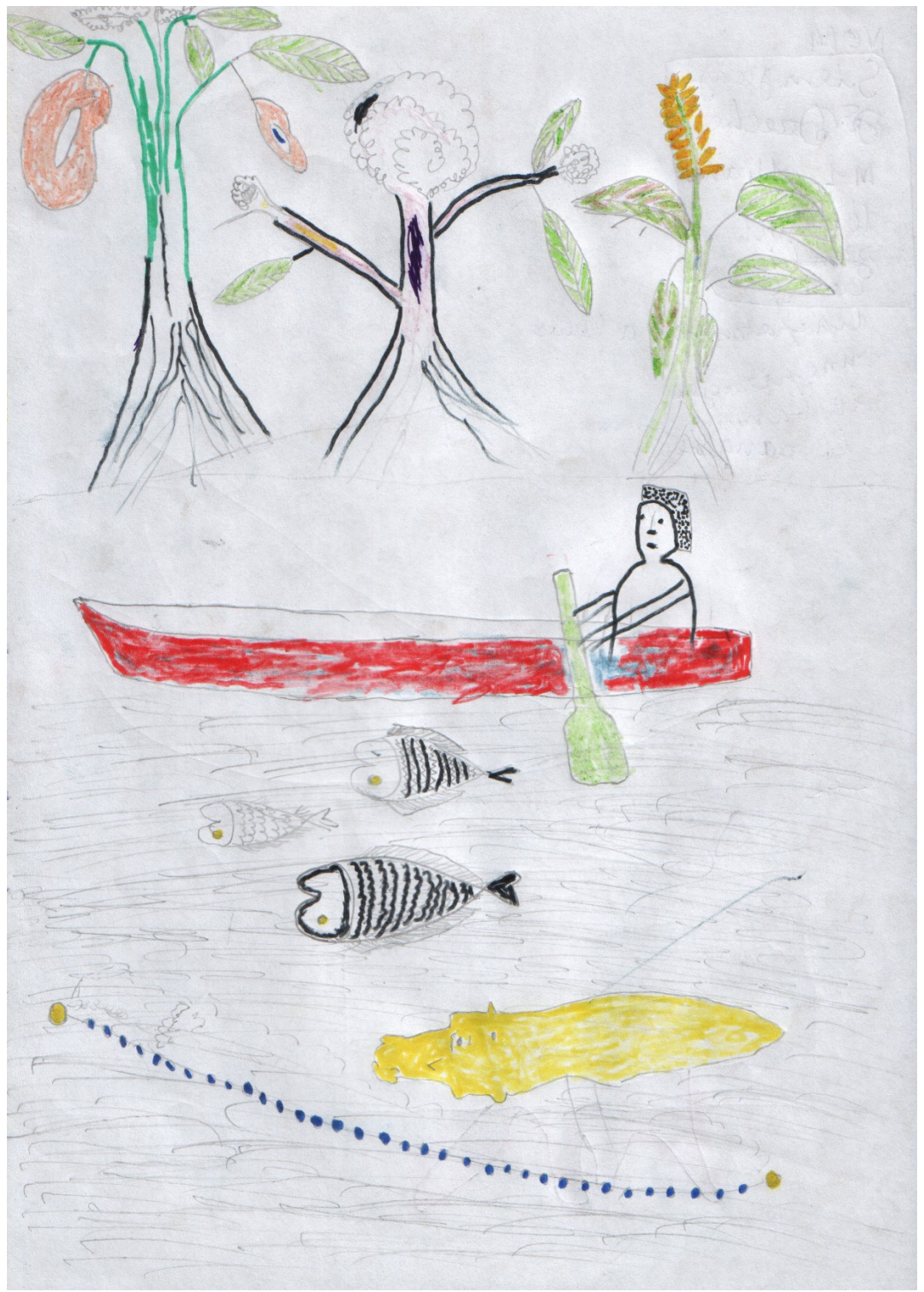

b) The boat - "Gabonese model" - is small, for one or two people, used for travelling and fishing in the lagoon.

\section{RESUltS AND LESSONS FROM THE GABONESE AND MALAGASY DRAWING EXPERIENCE}

Children's drawings can contribute to the collection of data on, and understanding of, children's ecological knowledge. This contribution may involve individual and collective knowledge, as well as both qualitative and quantitative data and analysis. It allows us to illustrate many ethnoecological domains observed and described during our fieldwork in Gabon and Madagascar.

\section{Domains of children's ecological knowledge}

Drawings are a useful means to apprehend people's knowledge and uses of plants and/or animals at the individual level, drawing being the representation of an individual at a particular stage in life (characterized by age, sex, personal and family history, education, culture...), but also at the collective level. The sum of these representations may be the reflection of a community, an ethnic group, an age class 
or a gender group. For example, drawings done in Gabon show that girls and boys represent their environment and how they dwell in it differently, especially regarding activities with their parents (Sabinot 2010). Whereas girls usually represented themselves and their mothers cooking or weighing fish (cf. Figure 6 below) on the beach, boys sketched themselves aboard a boat, fishing with their fathers ( $c f$. Figure 2 above).

Figure 6: M.G., 13-year-old girl, Gabon

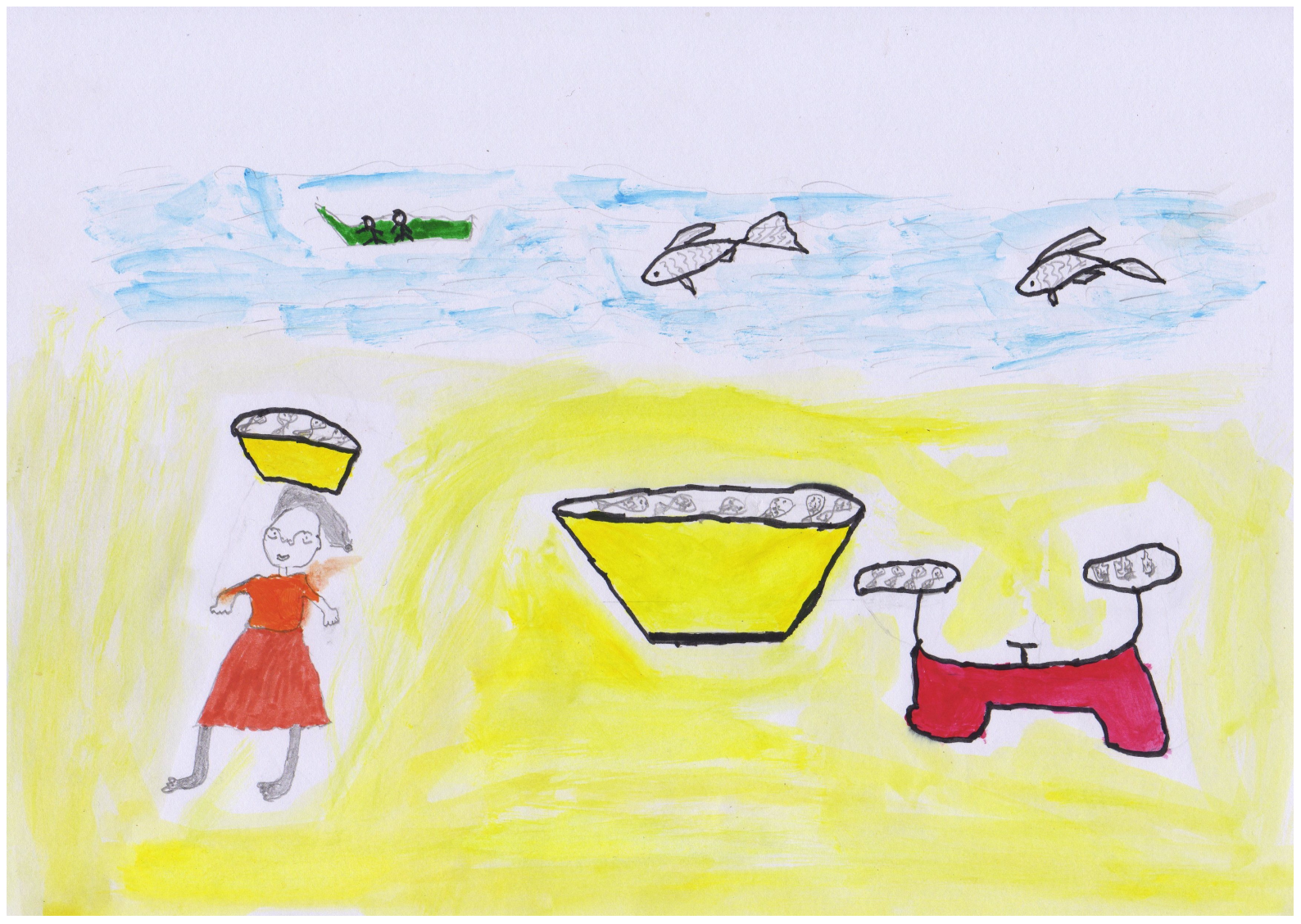

Weighing of fish on the beach. When the boats arrive on the beach, the Beninese women carry and weigh the sardines. Offshore, some sea bream (Podamasys sp., Pomadasyidae), fish well known to children, jump out of the water.

Drawings render it possible to shed light on ecological knowledge about crops and plants used for medicinal purposes, construction, rituals, and fiber (Reyes-García et al. 2007). Differentiating these specific domains of knowledge allows us to compare different individuals, even different groups of individuals, with regard, for example, to knowledge about wild ( $c f$. Figure 4 above) or cultivated species ( $c f$. Figure 3 above), and useful and non-useful species. We assumed that the drawings collected would largely reflect the knowledge domain involving the different components of nature (biotic and abiotic elements) as the main question posed was draw your nature/environment/surroundings7. However, as the question was "very open and encompassing", many ethnoecological domains were tackled in the drawings made

\footnotetext{
${ }^{7}$ Depending on the local language employed.
} 
in Gabon and Madagascar. Other instructions could have been chosen: draw the medicinal plants you know, or the crops you prefer to eat, or material you use to make your toys... Several layers of nested drawings may be used to get a comprehensive understanding of different overlapping knowledge domains. For example, to identify the representations and the relative importance of useful tree species for children and their community, the following instruction could be given before drawing: first draw the most useful species you use. Then to address medicinal plants, another nested instruction could be draw activities with your parents around the medicinal plants. These two guidelines may avoid the bias of having a child draw a pre-identified useful species that may not be the most important for the child and his/er community. It also allows one to understand what a useful species is for children.

Figure 7 R.R.R., 12-year-old boy, Betsileo region, Madagascar

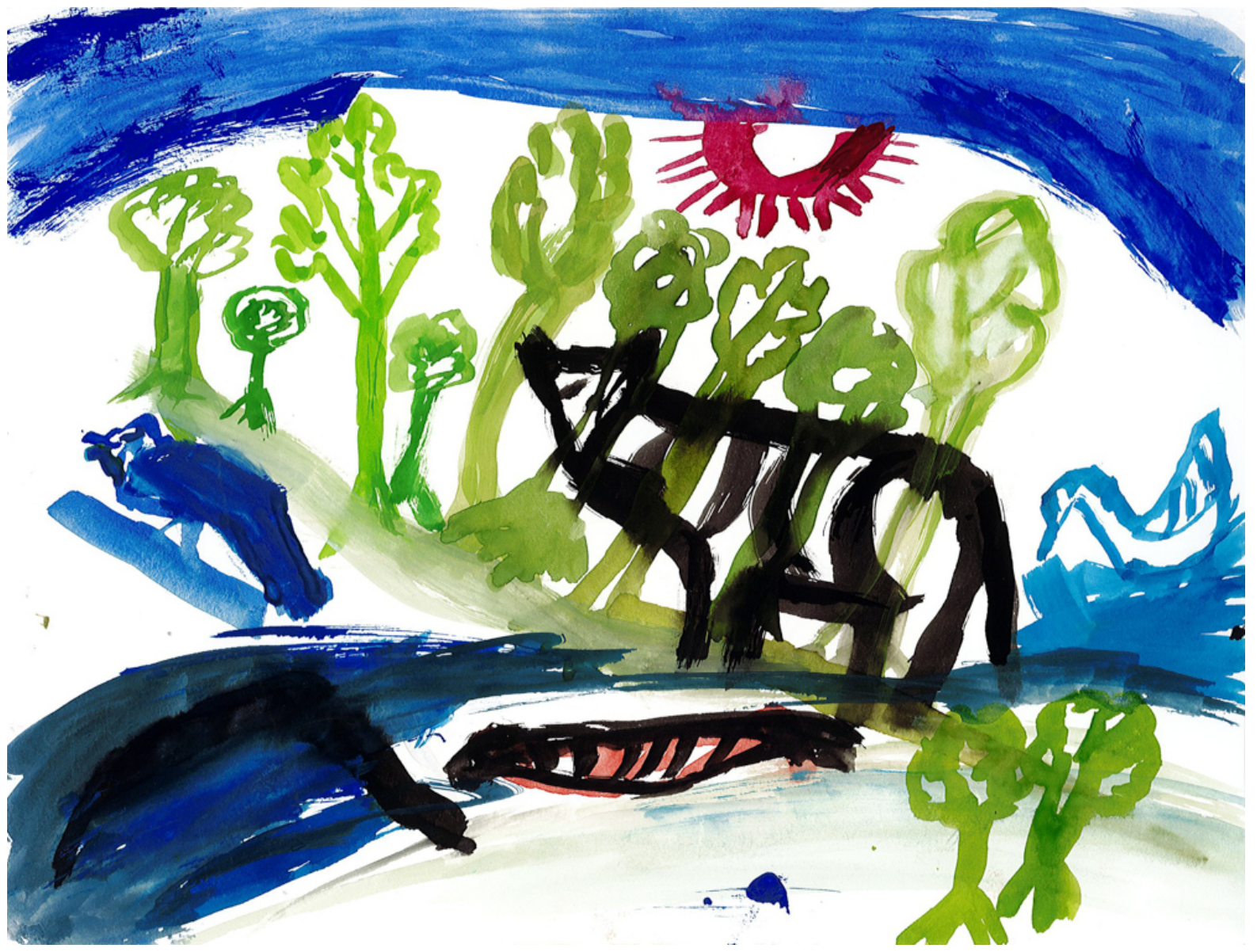

Representation of a tropical forest ecosystem including biotic elements such as trees, plants, animals (birds, lemurs, snakes and fish), abiotic elements (such as water stream and sources, sun, sky and rocks) and landscapes characteristics (exposition, topography).

The way a question is asked in an interview is crucial. The type of drawing instructions given and the way questions are answered enables one to obtain a specific, non-verbal, drawn response from each child, and may guide the given drawing and response. The drawing tool is thus useful for revealing and qualifying children's ecological knowledge, their "level" of knowledge, the spatial 
representation they have of their environment (ecosystem representation, $c f$. Figure 7 above), and the interactions they perceive between items (ecological processes and inter-species interactions, Figure 8 below).

By comparing the individual knowledge represented in drawings and the knowledge expressed by different groups of children, it is possible to confirm that children's ecological knowledge emerges from the given children's interaction with a local biophysical environment (Dounias 2007; Ferraris et al. 2015; Gallois et al. 2017; Warren \& Rajasekaran 1993). It also makes it possible to test whether indigenous groups have ecological knowledge developed through generations of interactions with the local environment (Turner et al. 2000). Finally, knowledge about the uses of items or skills may be collected when activities are represented in drawings.

Figure 8 R.M., 15-year-old boy, Betsileo region, Madagascar

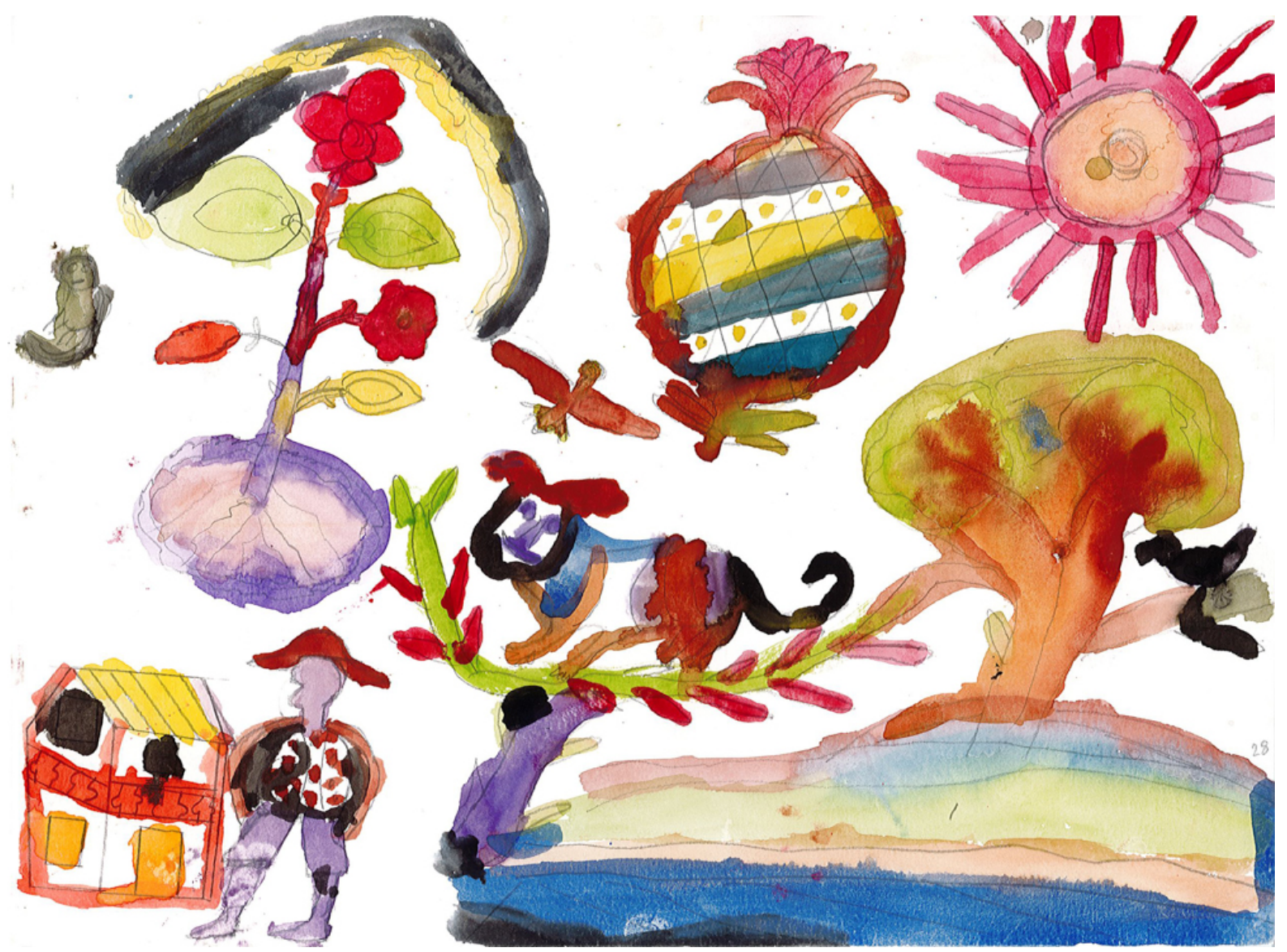

The known and described consumer and seed dispersal role and behavior of the lemur and bird present on the Ficus tree (they eat the fruits) attest to the ecological knowledge about plant and animal interactions of children in the forest zone. 


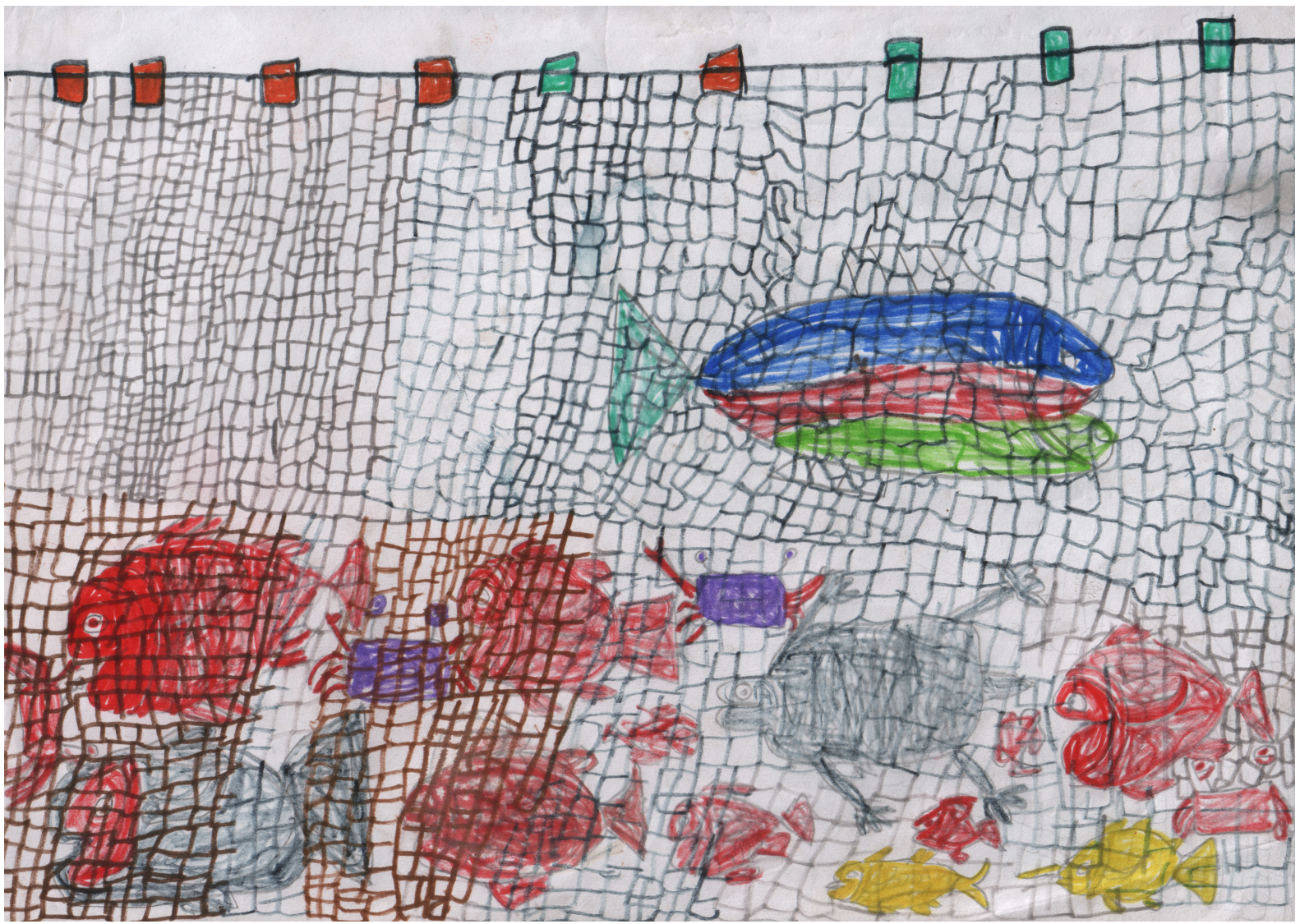

A net full of fish. The child listed the species on the back of his drawing: a red fish (Lutjanus sp., Lutjanidae, or Dentex sp., Sparidae), a black carp (Tilapia sp., Cichlidae), a sea bream (Podamasys sp., Pomadasyidae), a crab Callinectes sapidus, Portunidae) and a sea turtle (Lepidochelys olivacea, Cheloniidae).

\section{Contribution of drawings to quantitative and qualitative data collection and analysis}

To enhance understanding of the relationship between societies and their environment, and to contribute to reflection on the way populations acquire, adopt and share knowledge, combining the children drawing process with a classical ethnographical approach and ecological data collection allows researchers to strengthen qualitative and quantitative socio-environmental analyses. Due to its individual level approach, the drawing tool renders it possible, like an interview or survey, to collect children's "individual" ecological knowledge. In addition, children's drawings allow one to measure two different aspects of knowledge: theoretical or passive ecological knowledge (intellectual ability to name plants or animals in order to quantify, for example, the diversity of known species) and practical ecological knowledge, know-how or skills, i.e., the ability to put this knowledge into practice (intellectual ability to name plants and to recognize them practically). In Gabon, SDFP's drawing ( $c f$. Figure 9 below) shows a collection of fish, sea turtles and crabs that are easy to distinguish through the colors and shapes of animals, in particular regarding the tail, caudal and pectoral fins, etc. Similarly, a boy in Madagascar drew different trees and animals that he was able to name at the level of the family, the genus and sometimes the species level (R.J.C. drawing, $c f$. Figure 10 
below). R.J.C. knew and named eight taxa of trees and three taxa of wild animals that are found in his surroundings.

The narrative associated with these drawings measures practical knowledge (the capacity to name an item on the basis of morphological traits, or know-how). Interviews done after a drawing is finished enable one to understand why the child chose to represent an item as s/he did (colors, shapes, etc.) and to grasp how this knowledge is linked to a practical experience or use. The child who drew Figure 10 (cf. Figure 10 below) was able to explain how he is able to recognize each species. Due to the many botanical and morphological details depicted, this drawing is thus a means to measure practical knowledge. This drawing may also be interpreted by weighting the items that are drawn by their order of appearance in the drawing (from the largest, drawn first, to the least important, drawn last). It is also possible to deduce, as ethnobotanists do, which of the items being drawn are the best known, the most appreciated, the most used by the child or his/er parents, or the most abundant in the landscape (ecological apparency hypothesis, Lucena et al. 2012). A combination of these two tools (drawings and surveys) may potentially be used to compare theoretical and practical knowledge and, through repeated measures at different ages, to evaluate for example the moment when theoretical knowledge is acquired and when it turns into practical knowledge. Indeed, research shows that the transmission of ecological knowledge (nomenclature) is acquired during adolescence (Hunn 2002; Zarger 2002), but the practical aspects of this knowledge are acquired later in the life of the child, and sometimes during adulthood (Hewlett \& CavalliSforza 1986; Ohmagari \& Berkes 1997). Focusing on these two linked dimensions of ecological knowledge can therefore help to address issues of transmission to younger generations (Reyes-García et al. 2007).

In ethnoecology, the children's drawings approach constitutes a reliable, accurate and replicable method with standardized tools to collect quantitative and qualitative data on children's ecological knowledge. When studies use different methods to capture different dimensions of ecological knowledge, they generally are difficult to compare (Reyes-García et al. 2007). The drawing method, which combines two systematic tools (drawings and interviews), can capture many different dimensions of knowledge depending on the initial question.

Ecological knowledge results from interaction, a daily and renewed experience of the environment. Understood as "adjustments of societies with their environment", as arrangements "...or 'bricolages' between human groups and their environment that are maintained and show a relative adaptability, without necessarily disturbing the major characteristics of the system in place..." (Sabinot \& Lescureux forthcoming), ecological knowledge constitutes a privileged indicator of environmental changes. The evolution of some ecological knowledge could be monitored through participant observation and classical social science methodologies such as semi-structured interviews. Once the methodology is well 
established, and if the question asked children is well chosen, the analysis of drawings conceivably could be used to detect change. Once the methodology is well established, and if the question asked children is well chosen, the analysis of drawings conceivably could be used to detect change. Drawings could reveal a change in the interactions between a society and nature, triggering situated and focused fieldwork to complete the description of the change and to analyze the reasons for this evolution.

Figure 10: R.J.C., 14-year-old, boy, Betsileo region, Madagascar

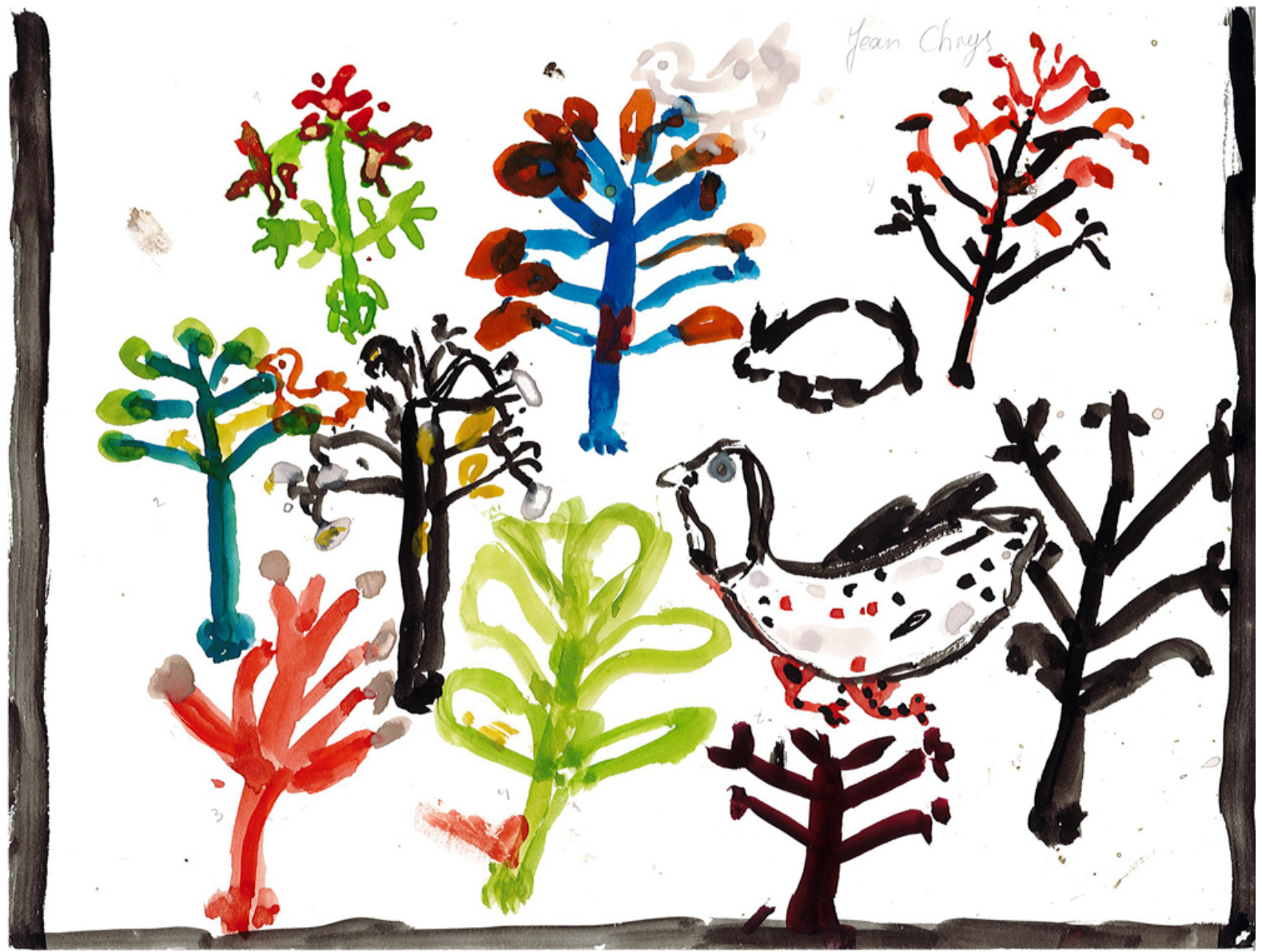

In this wooded landscape, he drew three wild animals: guinea fowl (Numididae) in black, a red fody Foudia madagascariensis, Ploceidae, and a hedgehog (Erinaceidae). All of the elements of this drawing are trees carefully drawn with different colors according to the species represented. Eight species of trees have been drawn with accuracy because they can be recognized by some small colorful details or forms that are very evocative. These species are: (1) Weinmannia rutenbergii, Cunoniaceae, in green and red (whose leaves are lobed and the young leaves at the top of the stems are red as observed in nature); (2) Dalbergia baronii, Fabaceae, the rosewood, in dark red as the color of the wood of this well-known timber species prized in Madagascar); (3) Harungana madagascariensis, Hypericaceae, in red, (whose leaves tends to be reddish); (4) Eucalyptus robusta, Myrtaceae, in blue (like the color of the adult leaves) and red (like the color of the young leaves), (one of the most widespread species in this landscape); (5) Allophylus pinnatus, Sapindaceae, in blue and green; (6) this same species but burnt (in black) as observed in slashed and burnt crop fields; (7) the burnt Harungana in black and red, and finally (8) a Rubiaceae species, in green, with its broad green leaves as observed in the forest (often designated generically hazondreniona, the eyes of the mother).

As in ethnoecology with adults, one must check the accuracy of the result provided through the drawing and the child's discourse. However, despite the standardized tools used, the instructions given before children begin to draw are not 
closed questions in the strict sense; they resemble more a free, open discussion that cannot be expected to be totally formatted. Moreover, contrary to responses given to a closed question, we must not expect from the drawing more than the reflection of a virtual, non-verbal image, that is, the reflection of knowledge shaped by the child, his or her history and representations of the outside world. In this sense, drawing joins a figurative and non-verbal thought whose degree of correctness cannot exist. As a result, the need for triangulation of information collected or even validation is significantly less important. In addition, the uniqueness and immediacy of a drawing must be taken into account as a response to a command, as opposed to a verbal response to a question, the contents of which will not change significantly from one day to another or from morning to evening.

However, it is possible to: (1) process information collected by comparing the responses of different children within the same cultural group or with those of children from another cultural group; (2) apply methods regularly used in ethnoecology such as cultural consensus analysis, which establishes that the degree of agreement between informants is an indicator of the importance of ecological knowledge; in the case of drawings, the more an item is drawn, the more it is important for this group of children (Johns et al. 1990); (3) compare the different items with scientific knowledge to evaluate the convergence between the colors and morphological traits used and noted by children in their representations and those observed in nature (this evaluation can be problematic in relation to the cultural subjectivity of children's perceptions of shapes and colors); and (4) calculate specific diversity indices (not directly on ethnospecies, but on items, Shannon index, Simpson index, species richness...) which will help to assess the diversity of the species of a given group, or the diversity of species known for a given ecosystem (e.g., forests); for this, however, specific, detailed recommendations must be given before the drawing session starts.

It is clear that a child's drawing essentially allows the quantitative analysis of theoretical knowledge more than practical knowledge (except for the determinations of plants and animals) and to quantify the items known by the children. Qualitative analysis is required to understand the significance of the spatial layout of items, the perceptions of interactions between items, and the symbolic value of items and their layout. To address the qualitative issues of a child's drawing, it is important to keep in mind that it has a projective value (perception of an environment and a vision of the world), an expressive value (technical gestures and graphic particularities, which we shall not analyze here), and finally a narrative value linked to the theme related by the drawing (Widlöcher 2002). In the interpretation of these different values, the various signs present in the drawing must be carefully explored at the time of the survey. In symbolic interpretation, it is also necessary to be able to identify the implicit allegories (i.e., which the child is not really aware of because they are part of 
his or her world) and the anthropomorphic meaning given to a plant, cloud or animal.

\section{Contribution of drawings to addressing classical ethnoecological themes}

The children drawing process may contribute to an integrative understanding of the way children and their society interact with their environment. As a complement to classical fieldwork, it is a relevant method in qualitative and quantitative ethnoecology. Background ethnoecological data about the current society must be acquired before the collection of drawings begins. This allows many dimensions and analytical issues to be combined throughout the entire process.

Figure 11: R.F., 12-year-old boy, Merina region, Madagascar

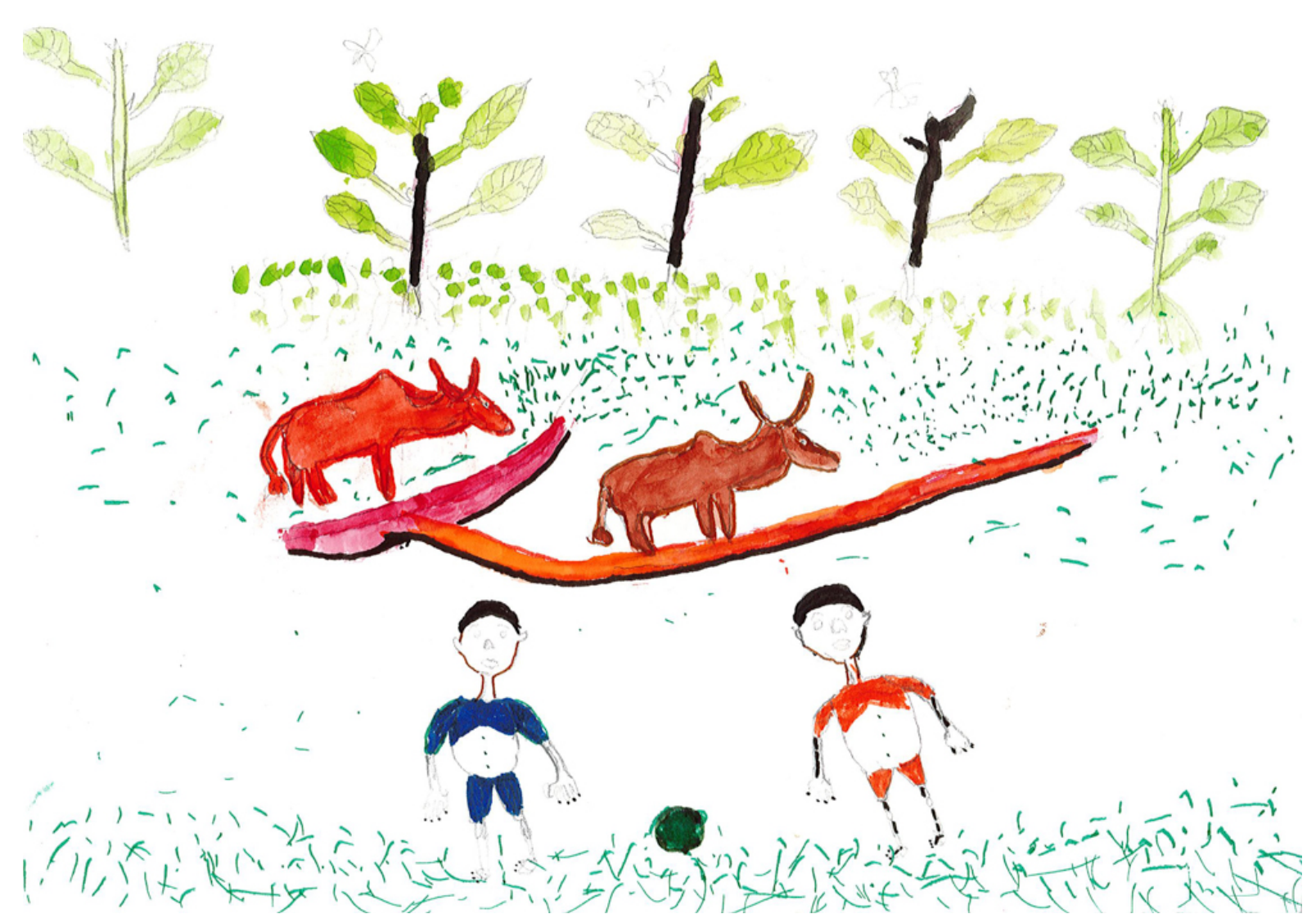

Grasslands are pastures. The animals drawn are zebus, which are watched by the boys who sometimes take the opportunity to play football.

In the important collection of children's drawings gathered by the authors and collaborators (Pagezy et al. 2010), most of the classical themes studied in ethnoecology were featured: (1) subsistence strategies with their main activities (such as fishing in Gabon, Greenland, Myanmar, Thailand and French Guyana, hunting in Siberia and Kamchatka, cattle and horse breeding in Kirghizstan and Madagascar, cultivation in Mayotte and Syria, gathering in Thailand); (2) the transmission of ecological knowledge and the representation of nature; (3) health and food with 
many examples of food preparation and transformation; and (4) the organization of work and the division of tasks by gender ( $c f$. Figure 11 above).

Each drawing related to these themes is a complementary tool to better describe and conduct interviews about children's knowledge and its articulation with the adult sphere. On the coast of Gabon, many drawings show fishing activities: in fresh and salt water, from the beach or aboard small or large boats. Subsistence activities are done by children alone (shrimp fishing with coconut palms in the river) or with adults of the family. Fishing gear and boats are usually drawn precisely. The analysis of the drawings shows that children have vast ecological knowledge: animal and vegetal species are differentiated, especially with regard to eaten species (cf. Figure 9 above). The question of the transmission of ecological knowledge, practices, nature representations and their learning was sometimes immediately raised during the interview. When the child describes his/her drawing, the roles of other children, an uncle, aunt, big sister or brother, mother or father, become obvious ( $c f$. Figure 2 above).

The observation of children's knowledge and representations in drawings and the articulation of this method with investigations conducted with adults may be useful to capture, understand and compare ethnoecological data about children and adults within each classical ethnoecological subtheme.

\section{Extension of drawing methods}

Drawings may also be used with adults, as was done to understand people's representations of volcano risks (Calandra 2013). Drawings collected in Vanuatu were used as a medium for semi-structured interviews to reveal how Ni-Vanuatu society conceives and interprets submarine risk (Calandra 2013). Drawings also may be used to assess campaigns to raise children's awareness of coral-reef ecosystems. This is the case of the Reso-Ecorail program, in which the authors are involved ${ }^{8}$. Children's drawings play a prominent role in the evaluation of this program, which follows a BACI method (before-after-control-impact). The objective is to understand changes in representations by instructing children to draw the sea or draw the coral reef. The assessment team is applying the drawing-based method in twenty elementary schools and is building a common analytic grid.

Another strength of this method lies in the possibility to conduct comparative and symmetrical analyses between various societies. Drawing permits massive comparative analysis. The surveyed (and thus sampled) population can be large since it is made up of all the children in a classroom. As the methodology and instructions are strictly identical, potential bias is limited as much as possible. More than 50 drawings can consequently be collected easily and rapidly, which is rarely the case in studies based on interviews with adults found in the literature, but this

\footnotetext{
$8 \mathrm{~J}$. Ferraris is the director of the RESO-ECORAIL, a program funded by Fondation de France https://www.fondationdefrance.org/sites/default/files/atoms/files/document_scientifique_-_littoral.pdf
} 
may require a lot of time to encode such data set. This may help and encourage a comparison (with different types of variables) between children and thus to report the variability of knowledge among them (Begossi 1996).

Many places and times can be suitable for using this tool when the manner of collecting, categorizing, questioning and analyzing drawings is a minima stabilized. However, as with the majority of tools and approaches used in ethnoecology, there may be constraints and difficulties in using and analyzing data from children's drawings. The main difficulty encountered relates first to data interpretation, understanding and triangulation, and second to the comparative dimension of the research. Indeed, the specificities of each of our fields imply numerous methodological adjustments related to the instructions given to the children and to the methodological choices of the survey, but also to the process itself during fieldwork. Tools must be socially adapted and accepted by local populations. These adaptations can then raise problems when harmonizing data collected in quite different ways, sometimes obtained with quite different questions. Another constraint is linked to the ease and rapidity of execution, which may encourage the use of drawing tools as a "quick and dirty" participatory approach (Cornwall \& Pratt 2011), although this method cannot be reliable without long-term fieldwork and deep knowledge of the society. Indeed, in the absence of the latter, there is a risk of misinterpretation. In our view, semi-structured interviews with children must accompany the analysis of their drawings if one is to better understand children's knowledge and describe their way of thinking about and living in the world. The direct consequence of this is that, as with a classical long-term approach in ethnoecology, one must be able to speak either the local language or work with a translator.

Beyond being an ethnoecological tool, the drawing process with children and adults offers many new perspectives in research, education and politics (Sabinot \& Carrière 2015). It may facilitate interactions between generations, disciplines, science and society. Indeed, through our experiences of collecting drawings, long-term fieldwork, exhibiting the drawings and ensuing interactions with the public, we can affirm that the drawing approach is an effective and sensitive means to transmit more than just scientific information and data (Sabinot \& Carrière 2015). One can truly speak of drawing as a facilitator for the dissemination of scientific knowledge to various target groups (public, other disciplines, local populations and donors for example), sometimes on particularly sensitive and political topics such as deforestation. These experiments have shown the interest of sharing researchers' personal experiences and thus capturing the attention of the public, which in turn provides a reaction, and even generates debates on scientific practices (Sabinot \& Carrière 2015). 


\section{CONCLUSION: ETHNOECOLOGY NEEDS DRAWING}

This article has shown the relevance of the children drawing methodology as an effective tool for data production in ethnoecology. The figuration process is a strong mediator because it sheds light on the relationships between children and their living places, as well as the representations children have of the latter (Pagezy et al. 2010). This paper indicates how children's ecological knowledge may be taken into account and thus "brought into the open" thanks to the use of the little-known but wellstandardized children drawing method. As noted by (Reyes-García et al. 2007), a constraint on the observation of ecological knowledge, and more generally on empirical ethnological research, is that the methods available are not always reliable or consistent. This may prevent comparisons of quantitative data about ecological knowledge and thus promote a proliferation of single-case studies. The children drawing method, inserted into a long term empirical approach, may be a standardized means to collect data on children's ecological knowledge that can complement qualitative research. Anchored in children's realities and imaginations, the representations of nature as presented in the drawings refer to both a social and ecological belonging that must be studied jointly (Carrière et al. 2010). Finally, according to ethnoecological research perspectives, we must keep in mind that a child's drawing is a picture that corresponds to a complex mode of expression whose full meaning can only be revealed through rigorous analysis accompanied by longterm fieldwork and deep knowledge of the society.

\section{Acknowledgements}

The authors of this article wish to thank all of the co-authors of the book Nature du monde: dessins d'enfants (CTHS 2010), as well as Serge Bahuchet, who has supported us from the start, writing in particular a magnificent preface to our work. We also thank Grace Delobel and Matthieu Salpeteur for their help and criticisms on the manuscript and the two guest editors of this special issue, Edmond Dounias and Yildiz Aumeeruddy-Thomas. Finally, we warmly thank all of the children who participated in the drawing workshops and their relatives for having trusted us.

\section{BIBLIOGRAPHY}

Atran S., MEdin D., Ross N., LyNCh E., VAPNARSKy V., EK E.U., COLEY J., TimURA C. \& BARAN M. 2002 « Folkecology, cultural epidemiology, and the spirit of the commons - A garden experiment in the Maya lowlands, 1991-2001 », Current Anthropology 43(3) : 421-450.

BATTESTI V. 2007 «'Pourquoi j'irais voir d'en haut ce que je connais déjà d'en bas ?' : Centralités et circulations : comprendre l'usage des espaces dans l'oasis de Siwa », Égypte/Monde Arabe 2006(3) : 139-181.

BEGOSSI A. 1996 « Use of ecological methods in ethnobotany : Diversity indices », Economic Botany 50(3) : 280-289.

BeRLIN B., BREEDLOVE D.E. \& RAVEN P.H. 1973 «General Principles of Classification and Nomenclature in Folk Biology », American Anthropologist 75 : 214-242.

CALANDRA M. 2013 «Faire dessiner le terrain : La nature à 'risques' et les jardins de subsistance de Tanna et Tongoa (Vanuatu)», Techniques \& Culture 60 : 182-201. 
CARRIERE S.M. 2010a «Les peuples des Hautes Terres malgaches. Le cadre de vie des agriculteurs betsiléo en lisière de forêt » (173-176), in H. Pagezy, S. Carrière \& C. Sabinot (eds.) Nature du monde, dessins d'enfants. Paris : CTHS.

CARRIERE S.M. $2010 b$ « Penser la nature : persistance et transmission du symbolisme animal et végétal des Betsiléo » (187-188), in H. Pagezy, S. Carrière \& C. Sabinot (eds.) Nature du monde, dessins d'enfants. Paris : CTHS.

CARRIERE S.M. 2010c « Représentation de la faune et de la flore sauvage par les peuples betsiléo » (183-185), in H. Pagezy, S. Carrière \& C. Sabinot (eds.) Nature du monde, dessins d'enfants. Paris : CTHS.

CARRIERE S.M. \& GASTINEAU B. 2010a « Les peuples des Hautes Terres malgaches. Le cadre de vie des riziculteurs merina » (169-171), in H. Pagezy, S. Carrière \& C. Sabinot (eds.) Nature du monde, dessins d'enfants. Paris : CTHS.

CARriere S.M. \& Gastineau B. $2010 b$ « Penser la nature. Perceptions et représentations de la nature par les enfants : comparaison entre Merina et Betsileo » (188-191), in H. Pagezy, S. Carrière \& C. Sabinot (eds.) Nature du monde, dessins d'enfants. Paris : CTHS.

CARRIERE S.M. \& GASTINEAU B. 2010c « Vivre la nature. L'omniprésence des espèces domestiques chez les Merina de Madagascar » (177-178), in H. Pagezy, S. Carrière \& C. Sabinot (eds.) Nature du monde, dessins d'enfants. Paris : CTHS.

CARRIERE S.M. \& GASTINEAU B. 2010d «Vivre la nature. Les activités agricoles des Merina selon les genres » (178-179), in H. Pagezy, S. Carrière \& C. Sabinot (eds.) Nature du monde, dessins d'enfants. Paris : CTHS.

CArriere S.M., SAbinot C. \& PAgezy H. 2010 «Conclusion » (251-253), in H. Pagezy, S. Carrière \& C. Sabinot (eds.) Nature du monde, dessins d'enfants. Paris : CTHS.

CORNWALl A. \& PRATT G. 2011 « The use and abuse of participatory rural appraisal : Reflections from practice, Agriculture and Human ", Values 28(2) : 263-272.

DOUNIAS E. 2007 «Tigres et dragons : les animaux symbolisant la forêt de Bornéo à travers des dessins d'enfants Punan Tubu » (351-393), in E. Dounias, É. Motte-Florac, M. Dunham (eds.) Le symbolisme des animaux: l'animal, clef de voûte de la relation entre l'homme et la nature? Paris: IRD Éditions.

ELLEN R. 1993 The cultural relations of classification. Cambridge : Cambridge University Press.

ELLEN R. 2006 Ethnobiology and the science of humankind. Oxford : Blackwell.

FERRARIS J., StOICA G. \& CHABANET P. 2015 «Représentation sociale des écosystèmes marins côtiers à partir de dessins d'enfants. Une étude comparative entre Tuléar (Madagascar) et Perpignan (France) », TrajEthos 4(1) : 49-67.

FOURNAND A. 2003 «Images d'une cité. Cartes mentales et représentations spatiales des adolescents de Garges-lès-Gonesse », Annales de Géographie 11(633) : 537-550.

FRIEDL E. 2002 «Why Are Children Missing from Textbooks? », Anthropology News 43(5) : 19-19.

GALLOIS S., DudA R. \& ReYes-GARCíA V. 2017 «Local Ecological Knowledge among Baka children: A case of Children's culture? », Journal of Ethnobiology 37(1) : 60-80.

GEARHART R. 2013 «Seeing life through the eyes of Swahili children of Lamu, Kenya : A visual anthropology approach », AnthropoChildren $3: 1-22$.

GHIMIRE S.K., MCKEY D. \& AUMEERUDDY-THOMAS Y. 2004 «Heterogeneity in ethnoecological knowledge and management of medicinal plants in the Himalayas of Nepal : implications for conservation », Ecology and Society 9(3): 6 . 
Hewlett B.S. \& CAVAlLI-SFORZA L.L. 1986 «Cultural transmission among Aka pygmies», American Anthropologist 88(4) : 922-934.

HIRSCHFELD L.A. 2002 "Why don't anthropologists like children? », American Anthropologist $104(2): 611-627$.

HUNN E.S. 2002 «Evidence for the precocious acquisition of plant knowledge by Zapotec children » (604-613), in J.R. Stepp, F.S. Wyndham \& R. Zarger (eds.) Ethnobiology and Biocultural Diversity. Athens : University of Georgia Press.

HUNN E.S. 2007 «Ethnobiology in four phases », Journal of Ethnobiology 27(1) : 1-10.

HVIDING E. 1996 « Nature, culture, magic, science. On meta-languages for comparison in cultural ecology» (165-184), in P. Descola \& G. Pálsson (eds.) Nature and Society. Anthropological perspectives. London : Routledge.

INGOLD T. 2004 «Beyond biology and culture. The meaning of evolution in a relational world », Social Anthropology 12(2) : 209-221.

JOHNS T., KOKWARO J. \& KiMANANI E. 1990 «Herbal remedies of the Batemi of Ngorongoro district, Tanzanie : A quantitative appraisal », Economic Botany 44 : 369-381.

Kull C.A., Carriere S.M., Moreau S., Rakoto Ramiarantsoa H., Blanc-Pamard C. \& TASSiN J. 2013 «Melting pots of biodiversity : tropical smallholder farm landscapes as guarantors of sustainability », Environment 55(2) : 6-15.

Lucena R.F.P., Muniz de Medeiros P., De Lima Araújo E., Chaves Alves A.G. \& AlbuQuerque U.P. 2012 «The ecological apparency hypothesis and the importance of useful plants in rural communities from Northeastern Brazil: An assessment based on use value ", Journal of Environmental Management 96(1) : 106-115.

LUQUET G.H. 1927 Le dessin enfantin. Paris : Alcan.

OHMAGARI K. \& BERKES F. 1997 «Transmission of indigenous knowledge and bush skills among the Western James Bay Cree woman of subarctic Canada », Human Ecology 25(2) : 197-222.

PAGEZY H., CARRière S.M. \& SABINOT C. 2010 Nature du monde : dessins d'enfants. Paris : CTHS.

Reyes-García V., MARTi N., MCDade T., TANNER S. \& VADEZ V. 2007 « Concepts and methods in studies measuring individual ethnobotanical knowledge ", Journal of Ethnobiology 27(2) : 182-203.

RUDDLE K. 1993 "The transmission of traditional ecological knowledge » (17-31), in J.T. Inglis (eds.) Traditional ecological knowledge: concepts and cases. Ottawa: International Program on Traditional Ecological Knowledge and International Development Research Centre.

SABINOT C. 2007 «Des hommes, des cultures, des savoirs et des savoir-faire en mouvement sur le littoral gabonais. Dynamique des savoirs et savoir-faire » (69-82), in P. Rouillard (eds.) Mobilités, immobilismes. L'emprunt et son refus. Paris : De Boccard.

SABINOT C. 2008. Dynamique des savoirs et des savoir-faire dans un contexte pluriculturel. Étude comparative des activités littorales au Gabon. Paris: Muséum National d'Histoire Naturelle, PhD Thesis.

SABINOT C. 2010 «Les pêcheurs autochtones et migrants du littoral gabonais » (106-127), in H. Pagezy, S. Carrière \& C. Sabinot (eds.) Nature du monde, dessins d'enfants. Paris : CTHS.

SABINOT C. \& CARRIERE S.M. 2015 «Le dessin d'enfant: de l'outil aux médias pour la diffusion des savoirs scientifiques» (51-71), in L. Vidal (ed.) Les savoirs des sciences sociales : débats, controverses, partages. Marseille : IRD Editions.

SABINOT C. \& LESCUREUX N. forthcoming « The Local ecological knowledge and the viability of the relations with the environment », in O. Barrière M. Behnassi, G. David, V. Douzal, M. 
Fargette, T. Libourel, M. Loireau, L. Pascal, C. Prost, V. Ravena Canete, F. Seyler \& S. Morand (eds.) Co-viability of social and ecological systems: Reconnecting mankind to the biosphere in a era of global change. Paris : Springer.

SAMUELSSON T., SpARRMAN A., CARDELl D. \& LindGReN A.L. 2015 « The active, competent child, capable of autonomous action : an inherent quality or the outcome of a research process?", AnthropoChildren 5 : 1-19.

SETALAPHRUK C. \& PRICE L.L. 2007 "Children's traditional ecological knowledge of wild food resources: a case study in a rural village in Northeast Thailand », Journal of Ethnobiology and Ethnomedicine 3(1) : 3-33.

TickTiN T. \& JOHNS T. 2002 «Chinanteco management of Aechmea magdalenae: Implications for the use of TEK and TRM in management plans », Economic Botany 56(2) : 177-191.

TOLEDO V.M. 1992 "What is Ethnoecology? Origins, scope, and implications of a rising discipline ", Ethnologica 1(1) : 5-21.

TURNER N.J., BOELSCHER IGNACE M. \& IGNACE R. 2000 « Traditional ecological knowledge and wisdom of aboriginal peoples in british columbia », Ecological Applications 10(5) : 1275-1287.

WARREN D.M. \& RAJASEKARAN B. 1993 "Putting local knowledge to good use », International Agricultural Development 13(4) : 8-10.

WIDLÖCHER D. 2002 L'interprétation des dessins d'enfant. Bruxelles : Mardaga.

ZARGER R. 2002 «Acquisition and transmission of subsistence knowledge by Q'eqchi' Maya in Belize» (593-603), in J.R. Stepp, F.S. Wyndham \& R. Zarger (eds.) Ethnobiology and biocultural diversity. Athens : University of Georgia Press.

ZARGER R. \& STEPP J.R. 2004 « Persistence of botanical knowledge among Tzeltal Maya children », Current Anthropology 45(3) : 413-418. 